\title{
20 Years and No Wrinkles - a Reason to Be Proud
}

\author{
Harald Walach $^{\mathrm{a}}$ Benno Brinkhaus ${ }^{\mathrm{b}}$ Peter Heusser $^{\mathrm{c}} \quad$ Dieter Melchart $^{\mathrm{d}} \quad$ Andreas Michalsen $^{\mathrm{e}}$ \\ Frauke Musial $^{f} \quad$ Bettina Reiter $^{\mathrm{g}}$ Reinhard Saller ${ }^{\mathrm{h}}$
}

${ }^{a}$ Institut für Transkulturelle Gesundheitswissenschaften, Europa-Universität Viadrina, Frankfurt/O.,

${ }^{b}$ Institut für Sozialmedizin, Epidemiologie und Gesundheitsökonomie, Charité Universitätsmedizin Berlin,

${ }^{c}$ Fakultät für Gesundheit (Department für Humanmedizin), Universität Witten/Herdecke,

d Zentrum für naturheilkundliche Forschung der II. Medizinischen Klinik und Poliklinik, Technische Universität München,

${ }^{e}$ Abteilung für Naturheilkunde, Klinik für Innere Medizin, Immanuel Krankenhaus Berlin, Germany

${ }^{f}$ National Research Centre in Complementary and Alternative Medicine, NAFKAM, Department of Community Medicine,

Faculty of Health Science, University of Troms $\varnothing$, Norway

${ }^{9}$ Private Praxis, Wien, Austria

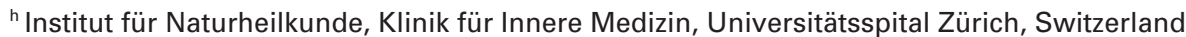

We recall vividly how, more than 20 years ago, a young Swiss researcher, Peter Jüni, contacted us trying to solicit support for a journal that was to be the first in documenting research in the new field of complementary and alternative medicine (CAM) research. A huge enthusiasm was able to secure the personal support for the project of Steven Karger, the publisher who in person and by the weight of his publishing house remained a strong and loyal supporter, and even after his sad and premature death in 2008 we can trust on that support. One of the current editors, Dieter Melchart, belonged to the original founders of the journal, others joined the editorial board, and all had been active in the field many years before. Others had just taken up research in CAM as a potential career option. Melchart was the only scientist in the field of CAM who succeeded in harnessing political support and government money from the Bavarian parliament for his work in Munich. He also brought in Alois Stacher who represented the Viennese 'Academy of Holistic Medicine' and Austria both of which are still represented in the journal through Bettina Reiter. Peter Matthiessen, then the only chair of 'Theory of Medicine and of Complementary Medicine' at the comparatively young University in Witten/Herdecke, Germany, became one of the driving forces of the movement and of the journal. His seminal work in drawing out a map of potential researchers in Germany for the German government unraveled, already in 1990, more than 100 research groups active or willing to become active in the field of CAM research in Germany alone. This was not only a good argument for a professional journal, but also for the government to start sponsoring research, which it did through the German Federal Research Department (BMBF) funded programs 'Unconventional Cancer Treatments' and later on 'Unconventional Medicine' [1]. Matthiessen brought his invaluable experience to the journal and served it for a long time until his professional retirement. But his legacy remains alive through Peter Heusser who, after his professorship in Berne, has succeeded him in the University of Witten/Herdecke as well as in the journal. A few years later the first chairs in the field were founded, one in Zurich and later also in Berne, demanded and set up in a democratic process by the population of these Swiss cities. The Swiss Society for Phytotherapy (SMGP) became the most important and loyal group supporting the journal, thereby, together with our other institutional subscribers, making it economically viable. Klaus-Michael Meyer-Abich, Germany's foremost philosopher of nature and medicine, and Marcella Ullmann, a medical journalist and writer, brought credibility and in-depth knowledge of the scene to the table. Young researchers joined the editorial board, to be succeeded and supported later by the still younger generation who now present the editors shaping Forschende KOMPLEMENTÄRmedizin / Research in Complementary Medicine and keeping it vibrant as the backbone of the journal.

With the journal going into its third decade, the members of the editorial board being already the second professional generation of researchers, and with a flurry of other specialized journals in the field that we have to compete with, we have demonstrated at least this: The field of CAM research is viable, it is robust in its outputs, it has grown in scope and

\section{KARGER \\ Fax +497614520714 \\ Information@Karger.com}

www.karger.com
(C) 2013 S. Karger GmbH, Freiburg

$1661-4119 / 13 / 0201-0005 \$ 38.00 / 0$

Accessible online at:

www.karger.com/fok
Prof. Dr. Dr. Harald Walach

Institut für transkulturelle Gesundheitswissenschaften Europa-Universität Viadrina

Große Scharnstraße 59, 15230 Frankfurt, Deutschland walach@europa-uni.de 
size, and it is continuing to produce high-quality research. Just as an aside: It was interesting to read that in the otherwise highly debatable meta-analysis of homeopathy trials by the Berne group around Matthias Egger the methodological quality of homeopathy trials was rated methodologically better in comparison with conventional trials. The field had matured and learned the lessons.

It should be remembered that, unlike other journals that are supported by large professional groups that are again financially supported by the industry and publish to a great extent research that is sponsored by the industry, the papers published in Forschende Komplementärmedizin / RESEARCH in Complementary Medicine are to the best part the work of independent researchers, sometimes funded by foundations, and very rarely funded by industry. This makes the journal a strong and independent voice in the chorus of publications whose independence is difficult to pitch, when the largest medical journals are financially dependent on direct or indirect industry sponsorship through the sales of offprints and adverts [2,3].

The journal has a good and friendly cooperation with the largest scientific professional body, the International Society of Complementary Medicine Research (ISCMR); 3 of the 4 presidents of ISCMR to date have been editors or advisory board members of the journal.

This jointly together constitutes, what a German court a while ago defined as constitutional for a scientific field: a tradition of publication and a tradition of scientific meetings and public discourse. The journal has been the backbone of publications and the public discourse, surely in Germany, but also radiating out internationally. The scientific field of CAM research is well and alive, as the articles in this special issue document. Major historical and current players have taken up the pen and reflected on the past and looked into the future of CAM and medicine in general. What we see is impressive: A scientific field has invented itself, out of the grassroots movement of people demanding and seeking a more holistic and active type of care than used to be offered by conventional medicine. There was no decision of any medical faculty, no legal action of political parties, and no real economic interest behind the birth of the field. This birth was not even driven by academia itself, which is normally the institution that defines new fields and developments through its discoveries. This new scien- tific discipline came from the grassroots: doctors - epitomized in Germany by the late Veronica Carstens who used her personal assets to support a foundation that started to approach researchers and build an infrastructure -, students - represented by the group around Melchart in Munich, who demanded teaching that included CAM -, and patients who began to become a force of their own, because sometimes researchers are patients and make their own experiences (the late Jacques Benveniste is an example of a researcher/patient turning into using research to explore CAM). We are not aware, in the modern history of science, of any other field that had so little support from mainstream academia, or rather resistance instead, so little funding from economically strong interest groups, and so much enthusiasm as its major driving force than CAM research, and that finally made it to become at least a respected discipline that, in Europe [4], USA [5], and elsewhere, now also has some political support.

Forschende Komplementärmedizin / Research In COMPLEMENTARy MEDicine was always at the front of the movement. If there was a mistake, then that we did not publish straight away in English, else the journal would have been the oldest international journal in the field, apart from the specialized homeopathy journals which are older. But that way, we are a German-based, European-focused, and internationally operating journal that addresses both a German and an international readership. We are proud that our editorial and advisory board are comprised of the most frequently cited and best known researchers in the field, who not only review and thereby shape the quality of the journal, but also publish their findings here. Thus, the journal is also a decisive element in establishing scientific credibility of the field and will be for many years to come. Often it can be heard that old-type journals like this one, with a publisher in the back - by the way, one of the very few owner-managed independent publishers -, an editorial board, and a reader who pays the bill is a model doomed to failure in the age of the internet. We beg to disagree: The more information will be freely available,

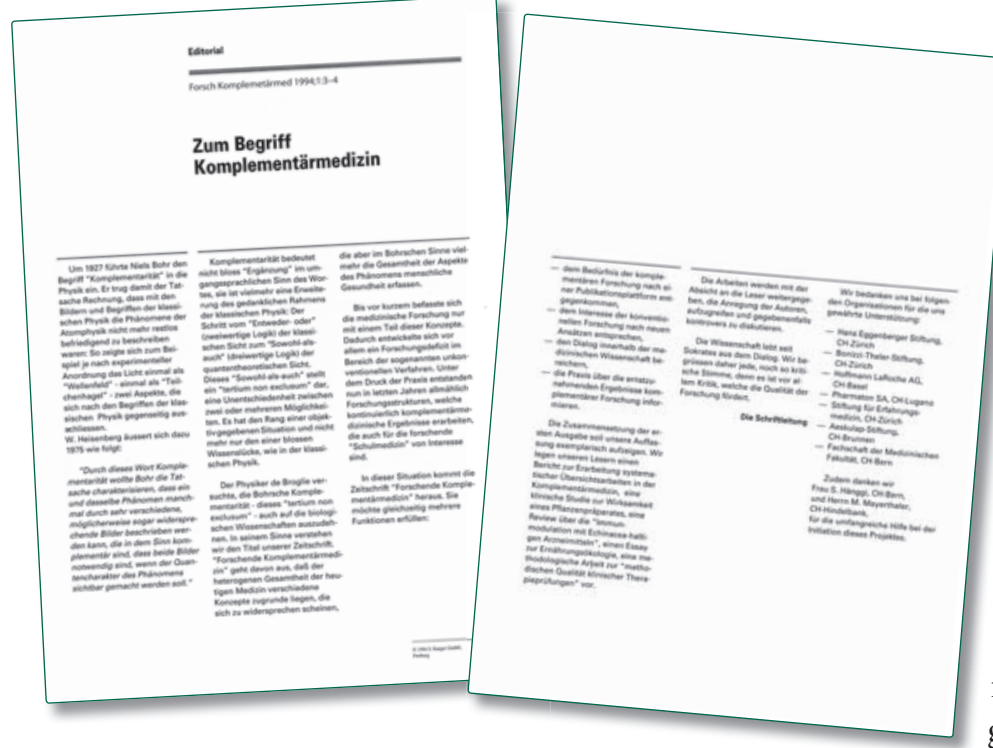
the more it will become important to understand which information is reliable. And finally, in the midst of all the freedom, the reader will want clearinghouses, groups, and platforms that really present what is trustworthy and reliable. And scientific journals such as ours are exactly that. They present reliable information. It is reliable, because it has been checked in a thorough peerreview process. We go to great lengths to find compe- 
tent reviewers. And since our reviewers also publish, they know the business and help shaping the publications we receive as submissions. It is through journals like this and the feedback they provide that young researchers learn how to publish in more widely read outlets.

For a while, we saw a tendency that strong and methodologically sound results were offered to and published by conventional journals. This was likely a honeymoon period of interest and fair play. This period seems to have gone by. Even very good papers are rejected 'for lack of interest for our readers' by mainstream journals. This will inevitably lead to the consolidation of the field, as authors will seek refuge with their papers in journals that they know are at least benevolent about the topic, if strict in the rating of methodological rigor. We are seeing this currently: Randomized studies of good methodological quality, comparative clinical cohort studies that might have made it into mainstream journals 10 years ago are now being published increasingly in specialized outlets such as this one.

So we are looking back on two decades of innovation and consolidation. Full of gratefulness to all those who have made it possible: the publisher, the authors, our reviewers, the pioneering figures who founded the journal, and all those who currently work to shape it, all cooperation partners and societies, and finally also all of our readers. We are looking forward to a future of solid scientific investigation that will hopefully, probably in a distant future, make this journal obsolete. This will have happened, when the insights of CAM research, that are currently seen as a specialized field outside the scope of biomedicine, are increasingly being integrated into medical practice and teaching, changing it, and making it more personcentered and holistic. How many generations of editors will be needed for this we do not know. But until then, we will be there helping to make it happen.

\section{References}

1 Matthiessen PF: Komplementärmedizin und Wissenschaftspluralismus - von der staatlichen Forschungsförderung zum Dialogforum Pluralismus in der Medizin. Forsch Komplementmed 2013; DOI: 10.1159000346849
2 Lundh A, Barbateskovic M, Hrobjartsson A, Gøtzsche PC: Conflicts of interest at medical journals: the influence of industry-supported randomised trials on journal impact factors and revenue - cohort study. PLoS Med 2010;7:e1000354.

3 Walker MJ: Dirty Medicine: The Handbook. London, Slingshot Publications, 2011.
4 Weidenhammer W, Walach H (eds): Insights into the current situation of CAM in Europe: major findings of the EU project CAMbrella. Forsch Komplementmed 2012;19(suppl 2):1-68.

5 Jonas WB: Complementary and alternative medicine and the NIH. Clin Dermatol 1999;17:99-103. 